\title{
Intravascular coil migration to bronchus: review of the literature with two case reports
}

\author{
Nur Aleyna YETKIN $\mathbf{1}_{(\mathrm{ID})}$ \\ Nuri TUTAR $\mathbf{2}_{(-,-1}^{2}$
}

${ }^{1}$ Clinic of Chest Diseases, Kayseri Training and Research Hospital, Kayseri, Turkey

${ }^{1}$ Kayseri Ĕ̆itim ve Araştırma Hastanesi, Göğüs Hastalıkları Kliniği, Kayseri, Türkiye

2 Department of Chest Diseases, Faculty of Medicine, Erciyes University, Kayseri, Turkey

2 Erciyes Üniversitesi Tıp Fakültesi, Göğüs Hastalıkları Anabilim Dalı, Kayseri, Türkiye
Cite this article as: Yetkin NA, Tutar N. Intravascular coil migration to bronchus: review of the literature with two case reports. Tuberk Toraks 2019;67(4):307-13.

Yazışma Adresi (Address for Correspondence)

\section{Dr. Nur Aleyna YETKIN}

Kayseri Eğitim ve Araştırma Hastanesi, Göğüs Hastalıkları, KAYSERI - TÜRKIYE e-mail: alleynakemik@gmail.com

CCopyright 2019 by Tuberculosis and Thorax.

Available on-line at www.tuberktoraks.org.com

\section{ABSTRACT}

Intravascular coil migration to bronchus: review of the literature with two case reports

Pulmonary vascular abnormalities are important causes of hemoptysis. Arteriovenous malformation (AVM), pulmonary arterial aneurysms or invasion of the pulmonary arterial structures by the tumor may cause hemoptysis. Pulmonary artery aneurysms (PAA) are an infrequent disease of the pulmonary vasculature. Endovascular coil application is a convenient treatment option for the treatment of hemoptysis due to vascular anomalies. The migration of intravascular coil to another tissue is a rare complication. To review this extremely rare complication, herein we report two unusual cases who had pulmonary artery aneurysm and who had hemoptysis due to tumor invasion to pulmonary artery, initially treated with endovascular coil successfully. In both cases endovascular coil was migrated to the bronchus subsequently. Lobectomy may be performed in such cases with coil migration into the bronchus or conservative therapy with follow-up chest imaging may be a suitable treatment option for selected patients. The choice of treatment should be made individually for each patient considering the characteristics of the patients. In patients with coils, the biopsy can lead to massive hemorrhages that are fatal.

Key words: Hemoptysis; endovascular procedures; bronchoscopy; aneurysm

ÖZ

İntravasküler koilin bronşa migrasyonu: iki olgu sunumu ile literatürün gözden geçirilmesi

Pulmoner vasküler anomaliler hemoptizinin önemli nedenlerinden biridir. Arteriyovenöz malformasyon (AVM), pulmoner arter anevrizmaları veya pulmoner arter yapılarının tümör tarafından invazyonu hemoptiziye neden 
olabilir. Pulmoner arter anevrizmaları (PAA), pulmoner damarların nadir görülen bir hastalığıdır. Endovasküler koil uygulaması, vasküler anomalilere bağlı ortaya çıkan hemoptizinin tedavisinde etkili bir tedavi seçeneğidir. Intravasküler koilin başka bir dokuya migrasyonu nadir görülen bir komplikasyondur. Bu nadir görülen komplikasyonun gözden geçirilmesi için, bu çalışmada pulmoner arter anevrizmasına sekonder ve pulmoner arterin tümoral invazyonuan sekonder gelişen hemoptizinin endovasküler yolla tedavi edildiği iki olgu sunulmuştur. Her iki olguda da endovasküler koilin daha sonra bronşlara migrasyonu gözlenmiştir. Bronş içine koil migrasyonu olan olgularda lobektomi yapılabilir ya da görüntüleme takibi ile konservatif tedavi uygun bir tedavi seçeneği olabilir. Tedavi seçimi, hastaların özellikleri göz önünde bulundurularak her hasta için ayrı ayrı yapılmalıdır. Endobronşiyal migrate koili olan hastalarda lezyonlardan biyopsi alınmaya çalışılması ölümcül kanamalara neden olabilir.

Anahtar kelimeler: Hemoptizi; endovasküler işlemler; bronkoskopi; anevrizma

\section{INTRODUCTION}

Migration of a coil which is used for endovascular treatment of vascular abnormalities to different tissues is rarely reported complication. Coil migration and extrusion have been reported in the bronchus, stomach, duodenum and colon (1-3). Aneurysm is defined as a focal enlargement that affects all three layers of the vascular wall. Pulmonary artery (PA) aneurysms are rare and infrequently diagnosed. Vast majority of pulmonary artery aneurysms remain asymptomatic. However hemoptysis has been described as a possible symptom and might be a warning sign for imminent aneurysm rupture (4). Another important cause of hemoptysis is tumor invasion of pulmonary vascular structures which can be successfully treated by endovascular coil placement. We describe two cases of coil migration to bronchus following endovascular treatment of pulmonary vascular abnormalities.

\section{CASE REPORTS}

\section{Case 1}

A 32-year-old female patient diagnosed with pulmonary thromboembolism two years before admission and treated with rivaroxaban $20 \mathrm{mg} /$ day. Approximately 1 week after the treatment with the rivaroxaban, the patient admitted to the emergency department with hemoptysis. The cause of hemoptysis was thought as the current rivaroxaban treatment so the treatment was changed with warfarin treatment. After three days, patient admitted to the emergency department with massive hemoptysis. On admission, the respiratory rate was $35 / \mathrm{min}$, the heart rate was $129 / \mathrm{min}$ and the finger saturation in room air was $87 \%$. Initial laboratory investigations were notable for Hemoglobin: $9.1 \mathrm{~g} / \mathrm{dL}$, WBC: $10.47\left(\times 10^{3} / \mu \mathrm{L}\right)$, international normalized ratio (INR): 5.9 , Sedimentation: $10 \mathrm{~mm} / \mathrm{h}$, C-reactive protein: $12.7 \mathrm{mg} / \mathrm{L}$. Chest radiography revealed increased bilateral bronchovascular branching and the consolidation in the right lower zone (Figure 1). Chest tomography showed segmental pulmonary artery filling defects and the grand glass opacity areas with the increased peribronchovascular branching on the right side (Figure 2,3). For preliminary diagnosis of the alveolar hemorrhage fresh frozen plasma and the steroid treatment was initiated. Pulmonary angiography revealed an aneurysmatic dilatation of the proximal branch of the pulmonary artery leading to the right lower lobe. The aneurysm was embolized with coils. It was learned that she had recurrent oral ulcers and skin lesions suggesting eritema nodosum for the last two years. The HLAB51 test for the differential diagnosis of Behçet's disease was found negative. However, the pathergy test was positive. The patient was diagnosed as Behçet's disease and methylprednisolone and cyclophosphamide treatment was initiated. Afterwards atelectasis was detected in right lung and bronchoscopy was performed. At the entrance of the right middle lobe, a lesion was seen whose the upper side was irregular and the lower side was regular (Figure 4). Bloody material was obtained by needle aspiration from the lower part of the lesion. Needle aspiration was done again from the upper side but no bleeding was observed. Bronchial

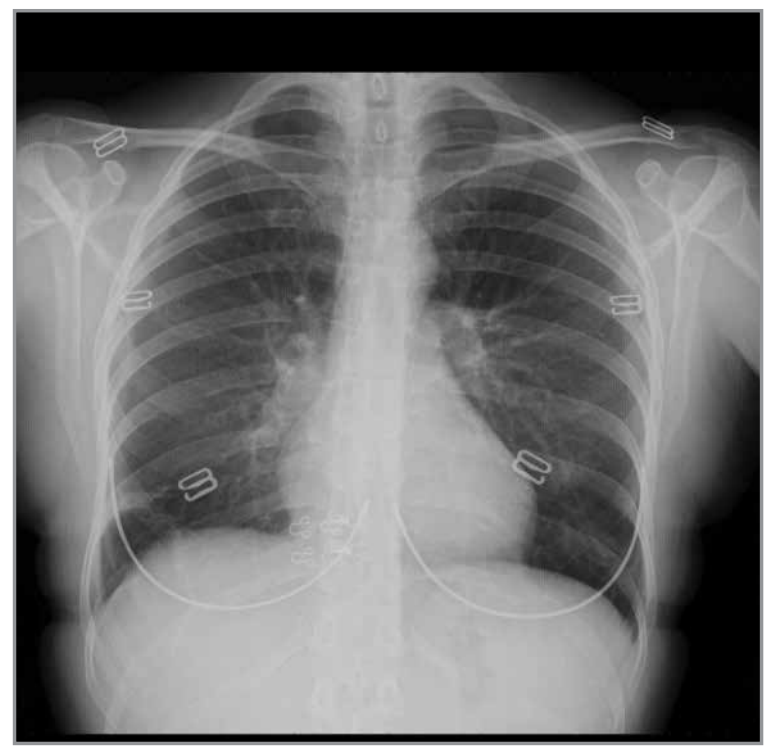

Figure 1. Chest radiography revealed increased minimal consolidation in right lower zone. 

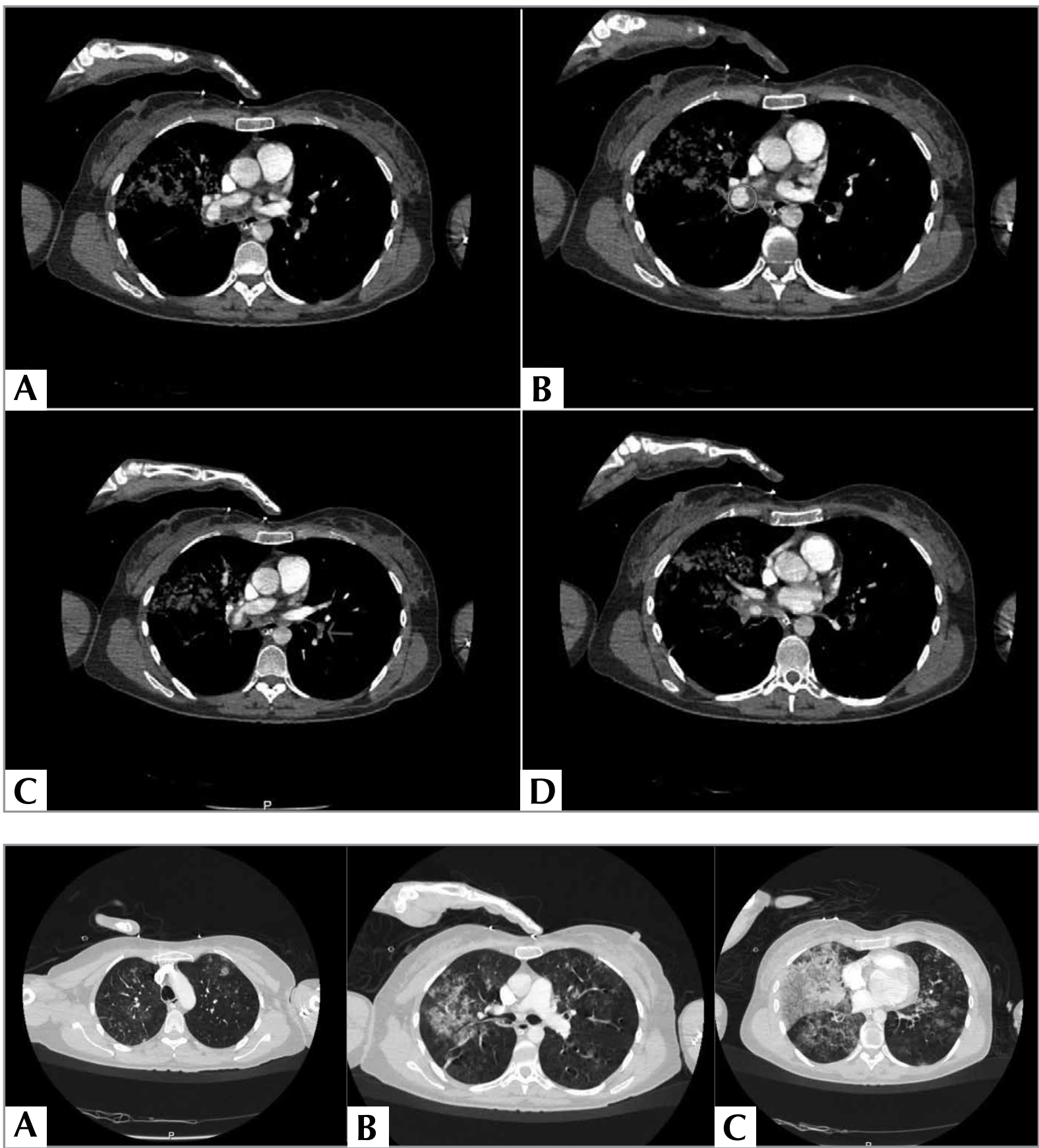

Figure 2,3. Chest tomography showed segmental pulmonary artery filling defects and grand glass opacity areas with increased peribronchovascular branching on right side.

biopsy was taken from here. Metallic lesion was seen underneath. The process was terminated when it became apparent that the foreign material was coil. Pathological evaluation of biopsy material revealed granulation tissue. Patient did not approve neither bronchial removal of coils nor lobectomy. Patient did not experience any additional complication related to coil or pulmonary hemorrhage and chest imaging findings remain stable in follow-up period. The patient was discussed at the council, and surgery was not recommended because she had vasculitis. She was treated with cyclophosphamide for six months and methylprednisolone for one year and methylprednisolone treatment was discontinued gradually. The patient had 
no complaints at the end of 2 years. In control bronchoscopy, only nodular intumescence was observed at the entrance of the middle lobe (Figure 5).

\section{Case 2}

A 50-year-old male patient with stage IV squamous cell lung cancer admitted with massive hemoptysis one year after diagnosis. Pulmonary artery and vein was invaded by the mass. Since $\mathrm{Hb}: 6 \mathrm{~g} / \mathrm{dL}$ was detected in routine laboratory tests, erythrocyte suspension transfusion was performed. After hemodynamic stability achieved, the patient underwent tomography scan. The chest tomography revealed that the mediastinal lymph nodes, the segmental pulmonary artery irregularity in the right lower lobe and the right hilar mass (Figure 6). At the angiography, extravasation was detected in the branch of the pulmonary artery leading to the right lung lower lobe, and a 4-8 $\times 16 \mathrm{~mm}$ graft-coated stent was inserted with the aid of a guide. Similarly, extravasation was observed in the right pulmonary vein. A graft-covered stent of $7 \times 22 \mathrm{~mm}$ was placed in the extravasation area with the aid of a guide. The hemoptysis of the patient decreased after the endovascular procedure.

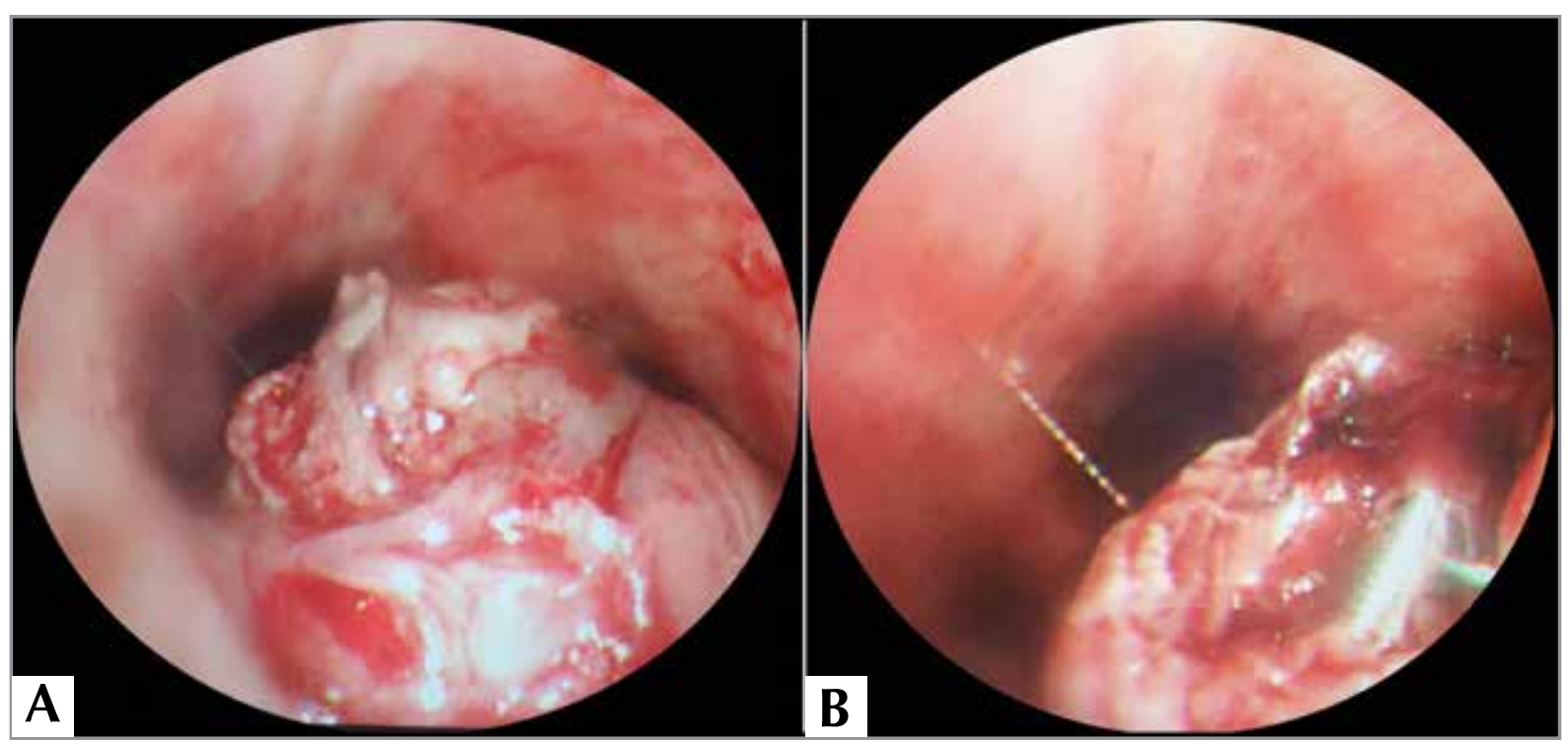

Figure 4. A. Well limited lesion at the medial lobe entrance, B. Foreign metallic object (coil) that comes out after biopsy.

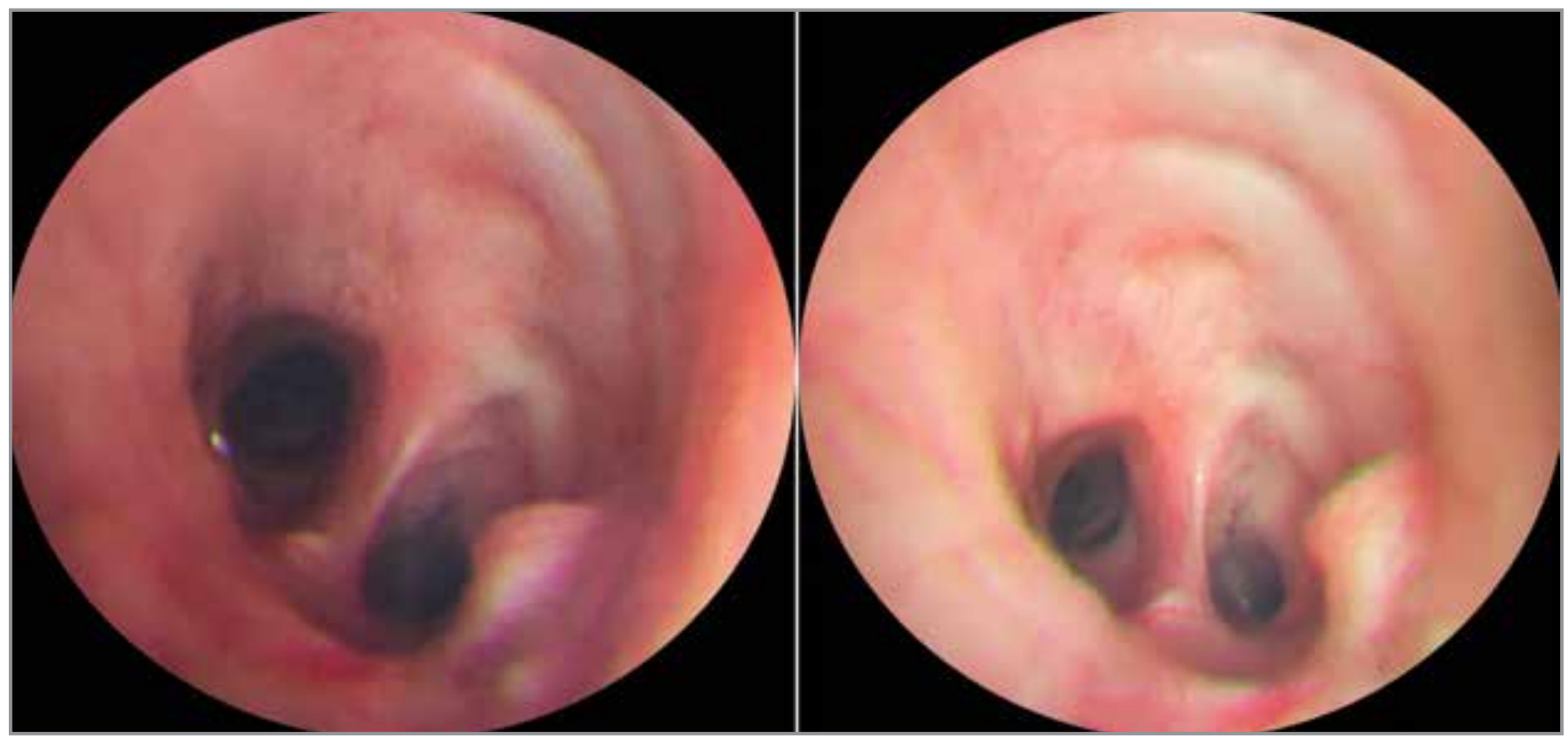

Figure 5. Control bronchoscopy revealed only nodular intumescence at the entrance of the right middle lobe. 


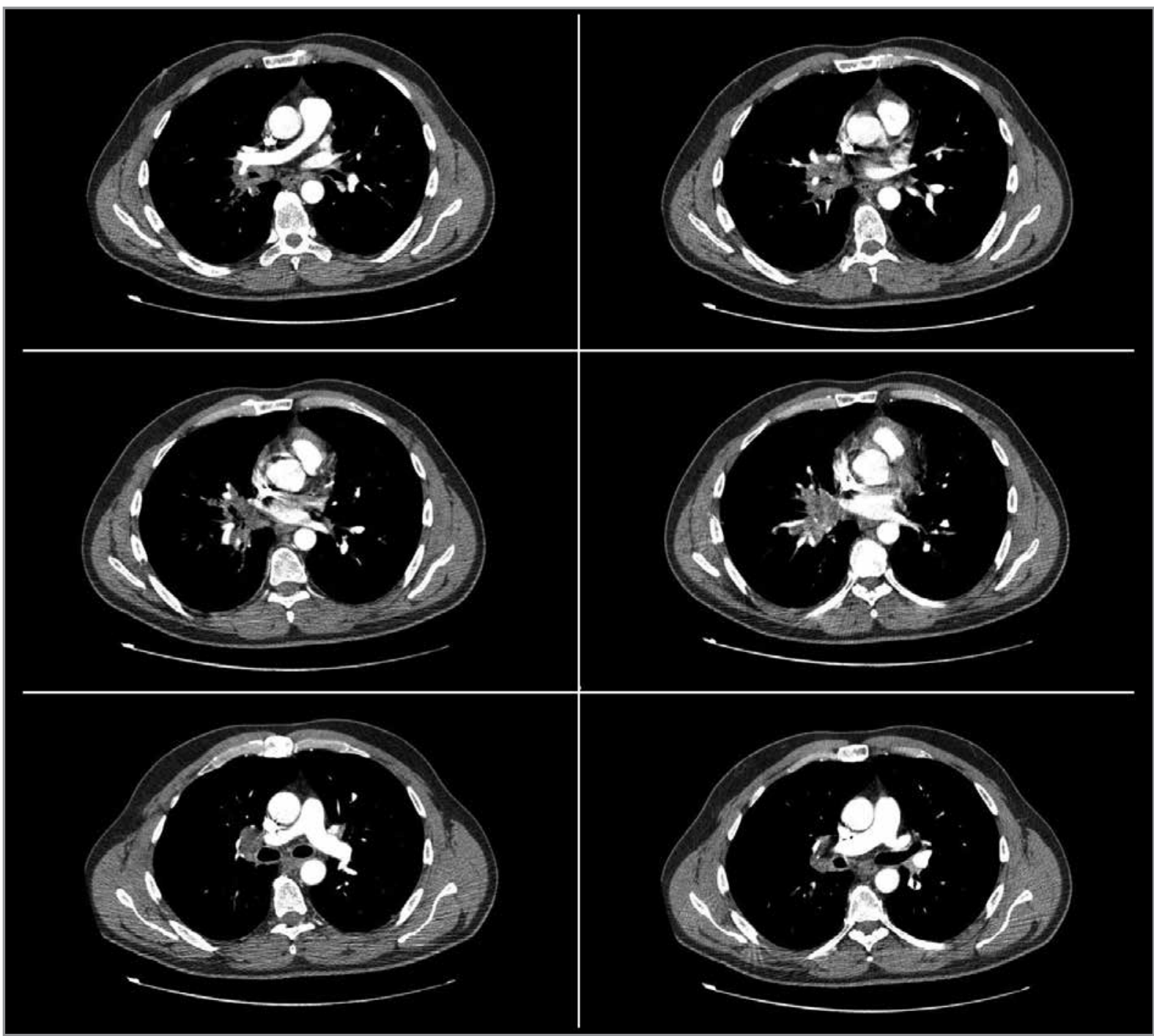

Figure 6. Chest tomography revealed mediastinal lymph nodes, segmental pulmonary artery irregularity in the right lower lobe and the right hilar mass.

One week later, control bronchoscopy was performed. Bronchoscopy revealed mucosal irregularity from intermediate bronchus to distant, tumoral infiltration, the narrowing of the bronchus and the foreign body like metallic structure at the level of the middle lobe bronchus (Figure 7).

\section{DISCUSSION}

Pulmonary vascular abnormalities are an important cause of the hemoptysis. Arteriovenous malformation $(\mathrm{AVM})$, pulmonary arterial aneurysms or invasion of the pulmonary arterial structures by the tumor may cause hemoptysis. Pulmonary artery aneurysms (PAA) are an infrequent disease of the pulmonary vasculature. Congenital and acquired causes such as vasculi- tis, infectious agents and neoplasms are associated with PAA, however the etiology remains unclear in some cases (4). Our first case presented with hemoptysis complaints and pulmonary arterial angiography showed a proximal pulmonary artery saccular aneurysm. Behçet's disease diagnosis was made by diagnostic workup. Initially aneurysm was successfully treated with coil however subsequently coil was migrated to bronchus as a result, atelectasis occurred. The first report on coil migration was made by Abad et al. Migration of the coil into the bronchus was detected six weeks after the embolisation of the saccular aneurysm (1). Second paper was published by DJ Wirtz et al. in which coil migration has been reported for the treatment of aortopulmonary collaterals that 


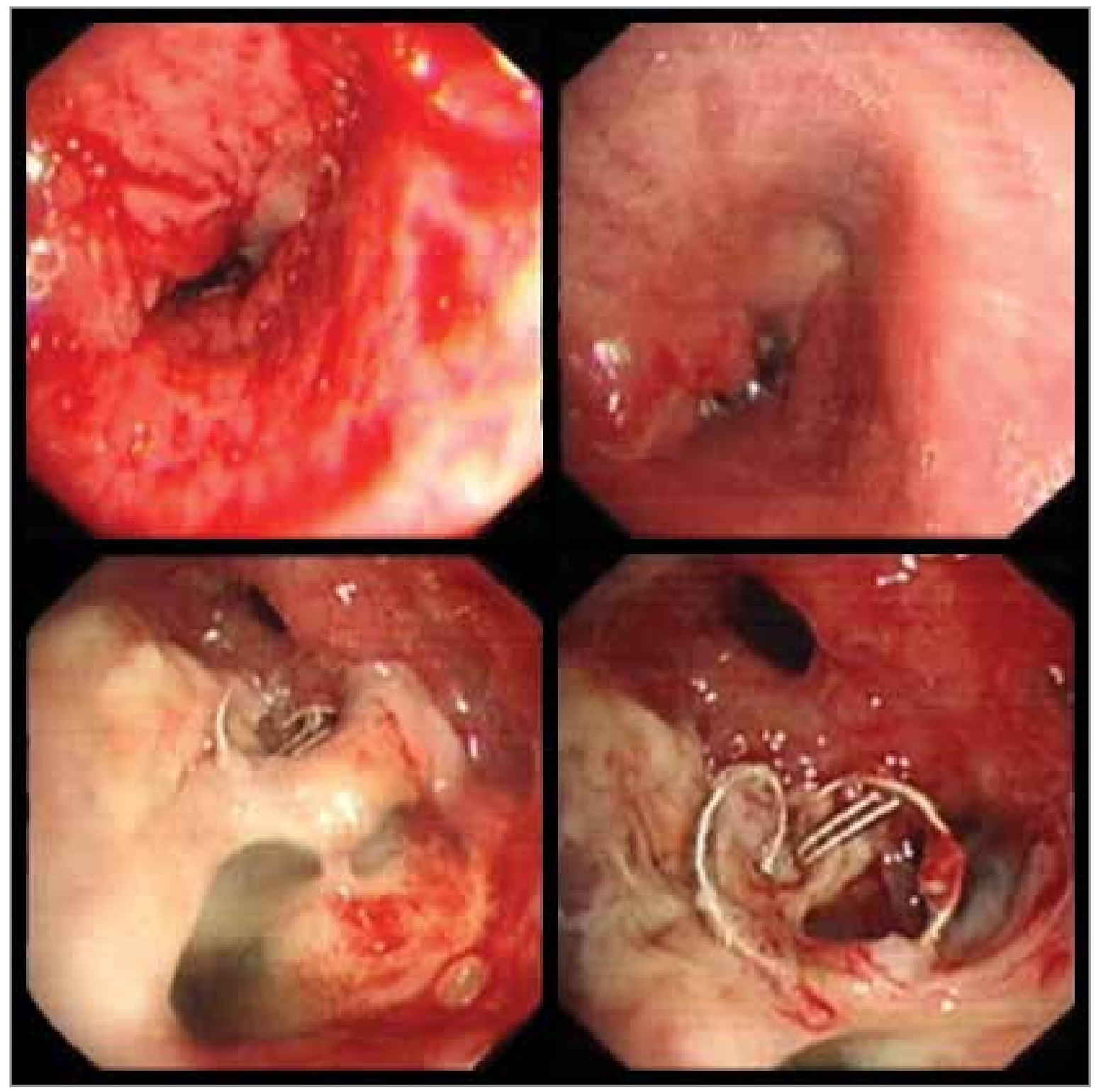

Figure 7. Bronchoscopy revealed mucosal irregularity from intermediate bronchus to distant, tumoral infiltration, narrowing of the bronchus and the foreign body like metallic structure at the level of the middle lobe bronchus.

develop secondary to the tetralogy of Fallot (5). The recent report was published by Tadashi et al. presenting a coil migration which was placed to threat an arteriovenous malformation (AVM) (6). Table 1 summarizes the clinical characteristics of the cases. The exact mechanism of coil migration remains unclear. Tadashi et al. concluded that weakness of the arterial wall, erosion of the adjacent bronchus, and failure of coils to maintain its spiral shape may be responsible from the migration. In addition, as in our second case, invasion of the vascular and bronchial walls by tumor cells can provide a basis for the migration of coil between these two tissues. At the same time, arterial pulsation can facilitate migration by pushing it toward the bronchial wall. However, it is noteworthy that massive pulmonary hemorrhage does not develop as a result of pulmonary artery trauma during migration. This situation can be explained by the fact that the migration gradually occurs over time and the vascular repair mechanisms are shifting and indeed in most cases coil migration did not cause any symptoms. Contrarily Tadashi et al. reported persistent bloody sputum as a migration symptom. 
Table 1. Bronch migrating coil reports

\begin{tabular}{|c|c|c|c|c|c|c|c|}
\hline Years & Authors & Age/Sex & $\begin{array}{l}\text { Initial clinical signs } \\
\text { and symptoms }\end{array}$ & $\begin{array}{l}\text { Type of vascular } \\
\text { abnormality }\end{array}$ & $\begin{array}{l}\text { Coil migration } \\
\text { symptoms }\end{array}$ & $\begin{array}{l}\text { Time from coil } \\
\text { placement to } \\
\text { detection of } \\
\text { migration }\end{array}$ & Treatment \\
\hline 1990 & $\begin{array}{l}\text { Abad, Javier, } \\
\text { et al. }\end{array}$ & $18 / \mathrm{M}$ & $\begin{array}{l}\text { Thoracic pain, } \\
\text { cough, hemoptysis }\end{array}$ & $\begin{array}{c}\text { Saccular } \\
\text { aneurism of } \\
\text { pulmonary artery }\end{array}$ & Asymptomatic & Six weeks & Lobectomy \\
\hline 2012 & $\begin{array}{l}\text { Wirtz, Dylan, } \\
\text { et al. }\end{array}$ & $40 / M$ & Unknown & $\begin{array}{l}\text { Aortopulmonary } \\
\text { collaterals due to } \\
\text { tetralogy of fallot }\end{array}$ & Unknown & Unknown & Unknown \\
\hline 2017 & $\begin{array}{c}\text { Umehara, } \\
\text { Tadashi, et al. }\end{array}$ & $56 / M$ & Unknown & $\begin{array}{l}\text { Arteriovenous } \\
\text { malformation }\end{array}$ & Hemosputum & 10 years & Lobectomy \\
\hline 2018 & $\begin{array}{l}\text { Current } \\
\text { Case } 1\end{array}$ & $32 / F$ & $\begin{array}{c}\text { Massive } \\
\text { hemoptysis }\end{array}$ & $\begin{array}{c}\text { Saccular } \\
\text { aneurism of } \\
\text { pulmonary artery }\end{array}$ & Asymptomatic & 2 weeks & Conservative \\
\hline 2018 & $\begin{array}{l}\text { Current } \\
\text { Case } 2\end{array}$ & $50 / \mathrm{M}$ & $\begin{array}{c}\text { Massive } \\
\text { hemoptysis }\end{array}$ & $\begin{array}{l}\text { Hemoptysis due } \\
\text { to tumor invasion } \\
\text { to pulmonary } \\
\text { artery }\end{array}$ & Asymptomatic & 3 weeks & Conservative \\
\hline
\end{tabular}

It is not clear how to treat the coil migration. Lobectomy was performed in two previously reported cases $(1,6)$. In our first case, lobectomy was planned but the patient did not accept the procedure. Immunosuppressive treatment was initiated for underlying vasculitis.

In our second case, lobectomy was not performed because of the insufficient lung reserve and the short survival expectancy. Both patients did not have any complications related to coil or hemorrhage in long term follow-up. Thus we conclude that conservative therapy with follow-up chest imaging may be a suitable treatment option for selected patients.

Endovascular coil application is a convenient treatment option for the treatment of hemoptysis due to vascular anomalies however it should be kept in mind that patients with pulmonary arterial coils, coil migration to bronchus is a rare complication in the presence or absence of a new symptom.

Lobectomy may be performed in such cases with coil migration into the bronchus, or the patient may be followed up by imaging without treatment. The choice of treatment should be made individually for each patient considering the characteristics of the patients.

\section{CONFLICT of INTEREST}

No conflict of interest declared by the authors.

\section{AUTHORSHIP CONTRIBUTIONS}

Concept/Design: NAY, NT

Analysis/Interpretation: NAY, NT

Data Acquisition: NAY

Writting: NAY, NT

Critical Revision: NT

Final Approval: NAY, NT

\section{REFERENCES}

1. Abad J, Villar R, Parga G, Fernandez R, Hidalgo EG, Nunez $V$, et al. Bronchial migration of pulmonary arterial coil. Cardiovasc Intervent Radiol 1990;13:345-6.

2. Dinter DJ, Rexin M, Kaehler G, Neff W. Fatal coil migration into the stomach 10 years after endovascular celiac aneurysm repair. J Vasc Intervent Radiol 2007;18:117-20.

3. Shah NA, Akingboye A, Haldipur N, Mackinlay JY, Jacob G. Embolization coils migrating and being passed per rectum after embolization of a splenic artery pseudoaneurysm, "the migrating coil": a case report. Cardiovasc Intervent Radiol 2007;30:1259-62.

4. Kreibich $M$, Siepe $M$, Kroll J, Höhn R, Grohmann J, Beyersdorf F. Aneurysms of the pulmonary artery. Circulation 2015;131:310-6.

5. Wirtz DJ, Bhatt NY, Roble SL, Ghosh S, Magalang UJ. Endobronchial erosion of vascular embolic coil. Am J Respir Crit Care Med 2012;185:682.

6. Umehara T, Aoki M, Kamimura G, Wakida K, Nagata T, Otsuka $T$, et al. Coil intrabronchial migration in an arteriovenous malformation patient treated 10 years ago. Ann Thorac Cardiovasc Surg 2017;23:200-2. 